\title{
The Detection and Attribution Model Intercomparison Project (DAMIP v1.0) contribution to CMIP6
}

\author{
Nathan P. Gillett ${ }^{1}$, Hideo Shiogama ${ }^{2}$, Bernd Funke ${ }^{3}$, Gabriele Hegerl ${ }^{4}$, Reto Knutti ${ }^{5}$, Katja Matthes ${ }^{6,7}$, \\ Benjamin D. Santer ${ }^{8}$, Daithi Stone ${ }^{9}$, and Claudia Tebaldi ${ }^{10}$ \\ ${ }^{1}$ Canadian Centre for Climate Modelling and Analysis, Environment and Climate Change Canada, \\ University of Victoria, Victoria, V8W 2Y2, Canada \\ ${ }^{2}$ Center for Global Environmental Research, National Institute for Environmental Studies, Tsukuba, 305-8506, Japan \\ ${ }^{3}$ Instituto de Astrofísica de Andalucía, CSIC, Glorieta de la Astronomía s/n, 18008 Granada, Spain \\ ${ }^{4}$ School of GeoSciences, University of Edinburgh, James Hutton Rd, Edinburgh, EH9 3FE, UK \\ ${ }^{5}$ Institute for Atmospheric and Climate Science, ETH Zürich, Universitätstrasse 16, 8092 Zürich, Switzerland \\ ${ }^{6}$ Ocean Circulation and Climate Dynamics, GEOMAR Helmholtz Centre for Ocean Research Kiel, 24105 Kiel, Germany \\ ${ }^{7}$ Christian-Albrechts-Universität zu Kiel, 24105 Kiel, Germany \\ ${ }^{8}$ Program for Climate Model Diagnosis and Intercomparison, Lawrence Livermore National Laboratory, Livermore, \\ California 94550, USA \\ ${ }^{9}$ Computational Chemistry, Materials and Climate, Lawrence Berkeley National Laboratory, Berkeley, California 94720, USA \\ ${ }^{10}$ Climate and Global Dynamics Laboratory, National Center for Atmospheric Research, Boulder, Colorado 80305, USA
}

Correspondence to: Nathan P. Gillett (nathan.gillett@canada.ca)

Received: 2 April 2016 - Published in Geosci. Model Dev. Discuss.: 14 April 2016

Revised: 2 September 2016 - Accepted: 13 September 2016 - Published: 18 October 2016

\begin{abstract}
Detection and attribution (D\&A) simulations were important components of CMIP5 and underpinned the climate change detection and attribution assessments of the Fifth Assessment Report of the Intergovernmental Panel on Climate Change. The primary goals of the Detection and Attribution Model Intercomparison Project (DAMIP) are to facilitate improved estimation of the contributions of anthropogenic and natural forcing changes to observed global warming as well as to observed global and regional changes in other climate variables; to contribute to the estimation of how historical emissions have altered and are altering contemporary climate risk; and to facilitate improved observationally constrained projections of future climate change. D\&A studies typically require unforced control simulations and historical simulations including all major anthropogenic and natural forcings. Such simulations will be carried out as part of the DECK and the CMIP6 historical simulation. In addition D\&A studies require simulations covering the historical period driven by individual forcings or subsets of forcings only: such simulations are proposed here. Key novel features of the experimental design presented here include firstly
\end{abstract}

new historical simulations with aerosols-only, stratosphericozone-only, $\mathrm{CO}_{2}$-only, solar-only, and volcanic-only forcing, facilitating an improved estimation of the climate response to individual forcing, secondly future single forcing experiments, allowing observationally constrained projections of future climate change, and thirdly an experimental design which allows models with and without coupled atmospheric chemistry to be compared on an equal footing.

\section{Copyright statement}

The works published in this journal are distributed under the Creative Commons Attribution 3.0 License. This license does not affect the Crown copyright work, which is re-usable under the Open Government Licence (OGL). The Creative Commons Attribution 3.0 License and the OGL are interoperable and do not conflict with, reduce or limit each other.

๑) Crown copyright 2016 


\section{Introduction}

Research into the detection and attribution (D\&A) of climate change is concerned with identifying forced changes in the observed climate record and assessing the roles of various possible contributors to those observed changes (Hegerl et al., 2010). This research is key for our understanding of anthropogenic climate change, as evidenced by a dedicated chapter in every assessment report of the Intergovernmental Panel on Climate Change (IPCC) since the first report published in 1990. Over this time the resources available to this area of research have developed considerably. Together with longer and improved observations of the climate system, D\&A research builds upon the analysis of simulations of the climate in the presence and absence of various factors which are expected to have affected the climate. D\&A analyses compare these retrospective predictions against the available observational record and, thus, serve as a comprehensive evaluation of our understanding of how the climate system responds to anthropogenic interference. Confidence in our ability to project future climate change hinges strongly on D\&A conclusions.

This paper describes a new coordinated international project to conduct D\&A simulations with the next generation of climate models, to be conducted as part of the Sixth Coupled Model Intercomparison Project (CMIP6, Eyring et al., 2016). The most basic sets of simulations required for D\&A analysis first became available from a large number of climate models through the Third Coupled Model Intercomparison Project (CMIP3, Meehl et al., 2007). At that time, individual forcing simulations allowing attribution investigations were carried out with over half a dozen models (Hegerl et al., 2007; Stouffer et al., 2016), but few of these were publicly available. It was not until the Fifth Coupled Model Intercomparison Project (CMIP5, Taylor et al., 2012) that the full suite of simulations needed for an assessment of the role of anthropogenic forcing, as well as of greenhouse gas emissions specifically, in observed climate trends was conducted using multiple climate models under a common experimental design and, moreover, made publicly available en masse.

D\&A studies using CMIP5 simulations underpinned several key high-level findings of the IPCC Fifth Assessment Report (AR5), including for example the assessment that "it is extremely likely that human influence has been the dominant cause of the observed warming since the mid-20th century", and a figure showing estimated contributions of greenhouse gases, aerosols, and natural forcings to observed temperature trends included as one of 14 summary figures in the summary of the IPCC AR5 Synthesis Report (IPCC, 2014). D\&A studies have also underpinned attribution assessments across a range of variables and regions (Bindoff et al., 2013) and have been used to constrain near-term projected warming (Stott and Jones, 2012; Gillett et al., 2012; Stott et al., 2013; Shiogama et al., 2016), as well as climate system parameters such as transient climate response (TCR) and the transient climate response to emissions (TCRE) (Allen et al., 2009; Gillett et al., 2013a). Hence D\&A results remain of key interest and relevance both scientifically and to policymakers. The only simulations targeted towards D\&A included as part of the CMIP5 experimental design were historical simulations with natural forcing changes only, and historical simulations with greenhouse gas changes only, which were used together with historical simulations and pre-industrial control simulations to support D\&A analyses. But research carried out since the design of CMIP5 has highlighted several key research questions which may be addressed by the inclusion of additional simulations in CMIP6.

The separate quantification of greenhouse gas and aerosol contributions to observed global temperature changes is important both for understanding past climate change and, since aerosol forcing is projected to decline while greenhouse gas forcing increases in the future, for constraining projections of future warming. While some earlier studies were apparently able to clearly separate the influences of greenhouse gases and other anthropogenic forcings on observed temperature changes using individual models (Stott et al., 2006), more recent studies using newer models and a longer period of observations have identified substantial uncertainties in the separate estimation of greenhouse gas and other anthropogenic contributions, where the other anthropogenic contribution is dominated by aerosols but also includes the response to ozone changes and land use changes in most models (Jones et al., 2013; Gillett et al., 2013a; Ribes and Terray, 2013). These larger uncertainties stem at least in part from uncertainties and inter-model differences in the simulated spatio-temporal pattern of response to aerosols (e.g., Ribes et al., 2015; Boucher et al., 2013), which may have been exacerbated by the large amount of sampling variability in estimates of the aerosol response derived from a difference between the historical simulations and historical simulations with greenhouse gases only and natural forcings only (e.g., Ribes and Terray, 2013). Simulations of the response to historical changes in aerosols alone will allow the calculation of the response to aerosol forcing with less contamination from internal variability, and without conflating the effects of aerosols with the response to other forcings, most notably ozone and land use changes. Such aerosol-only simulations may be used together with historical simulations including all forcings and historical simulations with natural forcings only to estimate attributable contributions to observed changes due to natural forcings, due to aerosols, and due to the combined effects of well-mixed greenhouse gases, ozone, and land use changes. Since some part of the greenhouse gas changes is associated with land use change, and since ozone is a greenhouse gas, grouping these forcing together arguably makes more sense than grouping ozone and land use change with aerosols. Comparisons of these aerosolonly simulations with proposed Radiative Forcing Model Intercomparison Project (RFMIP, Pincus et al., 2016) simulations will allow the separation of uncertainty in the simulated 
aerosol response into a component associated with differences in the simulated distribution of aerosols and a component associated with differences in the simulated climate response to a given aerosol distribution. These advances should allow a more robust quantification of the response to aerosol forcing and its uncertainties.

A further key contribution of D\&A studies to the findings of the IPCC AR5 was through the use of observationally constrained climate projections to inform the assessed range of near-term warming (Stott and Jones, 2012; Gillett et al., 2012; Stott et al., 2013; see also Shiogama, et al., 2016). This is achieved by scaling the projected responses to greenhouse gases and aerosols by their respective regression coefficients derived from a regression analysis over the historical period (Allen et al., 2000; Stott and Kettleborough, 2002; Kettleborough et al., 2007). Such analyses rely on both individual forcing simulations covering the historical period, which were included as part of CMIP5, and individual-forcing simulations of the future, which were not. The latter are required for constraints on projections under scenarios of future emissions in which the relative importance of greenhouse gases to the other anthropogenic forcings changes from that in the historical experiments. Such studies carried out to date have relied on simulations provided by a small number of climate models (Bindoff et al., 2013; Shiogama et al., 2016): the inclusion of future simulations with individual forcings in CMIP6 will allow the derivation of more robust observationally constrained projections based on a broader range of models, as well as the facilitation of studies of the aerosol contribution to projected future climate change, which is an area of increasing scientific interest (Shiogama et al., 2010a, b; Gillett and von Salzen, 2013; Gagné et al., 2015; Rotstayn et al., 2013; Myhre, et al., 2015).

The experiments proposed as part of DAMIP (Table 1 and Fig. 1) will facilitate a number of D\&A analyses of anthropogenic and natural forcing influences on historical climate changes. These analyses are expected to address historical changes in temperature, the hydrological cycle, the atmospheric circulation, ocean properties, cryospheric variables, extreme indices, and other variables, from global to regional scales (Bindoff et al., 2013). The extension of DAMIP experiments from 2012 in CMIP5 to 2020 with updated climate forcings will support better understanding of the period of reduced warming in the early 21st century (Meehl et al., 2011; Watanabe et al., 2014; Huber and Knutti, 2014; Schmidt et al., 2014) and improve the signal-to-noise ratio for D\&A of changes in high-noise variables such as precipitation (Zhang et al., 2007). These DAMIP experiments are particularly relevant to two of the major CMIP6 science questions. Analysis of individual forcing simulations and attribution studies of observed changes will help us to understand how the Earth system responds to forcing, and their use to derive observationally constrained projections will improve our assessments of future climate change. The DAMIP experiments are also very relevant to the WCRP Grand Challenge on ex- tremes: DAMIP simulations will support attribution studies of changes in temperature, hydrological, and other extremes and will improve understanding of the drivers of observed changes in extremes, as well as improving our assessment of the present-day probabilities of extremes. This effort will be further facilitated by using output from DAMIP simulations as input to the $\mathrm{C} 20 \mathrm{C}+$ Detection and Attribution Project (Stone and Pall, 2016) and other similar projects which use ensembles of simulations of atmosphere-only models driven using observed sea surface temperatures and sea ice, and other similar experiments in which attributable anthropogenic changes are removed from the prescribed sea surface temperatures and sea ice to quantify the contribution of anthropogenic changes to individual extreme events. Such studies rely on historical simulations and historical simulations with natural forcings only, such as those included in DAMIP to quantify anthropogenic changes in sea surface temperatures. Attribution studies based on DAMIP output of hydrological changes and cryospheric changes will also address the WCRP Grand Challenge on water availability and cryospheric change.

We do not include an analysis plan here, because the field of detection and attribution is well-established, and past experience indicates that individual groups are able to selforganize and to carry out attribution studies on variables and regions of interest. Numerous attribution studies were carried out using the CMIP5 attribution simulations (Bindoff et al., 2013), and it is expected that this number will only increase for DAMIP. D\&A activities are coordinated internationally in part by the International Detection and Attribution Group (Barnett et al., 2005), and the long-standing interest of the IPCC in attribution will likely also prompt analysis. Therefore our scope here is restricted to explaining and justifying the planned DAMIP simulations.

\section{Experimental design}

There are two possible frameworks for designing climate model experiments for D\&A analysis: the "only" approach, in which simulations are driven with changes only in the forcing of interest, while all other forcings are held at preindustrial values; and the "all-but" approach, in which simulations are driven with changes in all forcings except the forcing of interest. An example of the latter is the LUMIP histNoLu simulation which includes changes in all forcings but land use change (Lawrence et al., 2016). The two approaches yield equivalent results if additivity holds (i.e., if the climate response to the combined forcing is equal to the sum of the responses to the individual forcings, e.g., Rogelj et al., 2012; Knutti and Hegerl, 2008) and in the limit of large ensembles but can differ otherwise. The additivity assumption appears to hold for certain forcings, magnitudes, spatial scales, and variables (e.g., Meehl et al., 2004; Gillett et al., 2004; Shiogama et al., 2013) but may not hold for others (Schaller et 
Table 1. List of proposed DAMIP experiments.

\begin{tabular}{|c|c|c|c|c|c|}
\hline $\begin{array}{l}\text { Name of } \\
\text { experiment }\end{array}$ & Description (forcing agents perturbed) & Tier & $\begin{array}{l}\text { Start } \\
\text { year }\end{array}$ & $\begin{array}{l}\text { End } \\
\text { year* }\end{array}$ & $\begin{array}{r}\text { Min } \\
\text { ensemble } \\
\text { size }\end{array}$ \\
\hline $\begin{array}{l}\text { CMIP6 histori- } \\
\text { cal simulation } \\
\text { and SSP2-4.5 }\end{array}$ & $\begin{array}{l}\text { Enlarging ensemble size of the CMIP6 historical simulations (1850-2014) } \\
\text { and the SSP2-4.5 simulations of ScenarioMIP (2015-2020). While these } \\
\text { simulations are called historical in this paper for readability, please provide } \\
\text { the output data separately as the CMIP6 historical simulation }(-2014) \text { and } \\
\mathrm{SSP} 2-4.5 \text { (2015-) (as historical: WMGHGs, } \mathrm{BC}, \mathrm{OC}, \mathrm{SO}_{2}, \mathrm{SO}_{4}, \mathrm{NO}_{x} \text {, } \\
\mathrm{NH}_{3} \text {, CO, NMVOC, nitrogen deposition, ozone, stratospheric aerosols, solar } \\
\text { irradiance, land use). }\end{array}$ & 1 & 1850 & 2020 & 3 \\
\hline hist-nat & Natural-only historical simulations (solar irradiance, stratospheric aerosol) & 1 & 1850 & 2020 & 3 \\
\hline hist-GHG & Well-mixed greenhouse-gas-only historical simulations (WMGHGs) & 1 & 1850 & 2020 & 3 \\
\hline hist-aer & $\begin{array}{l}\text { Anthropogenic-aerosol-only historical simulations (BC, } \mathrm{OC}, \mathrm{SO}_{2}, \mathrm{SO}_{4} \text {, } \\
\left.\mathrm{NO}_{x}, \mathrm{NH}_{3}, \mathrm{CO}, \mathrm{NMVOC}\right)\end{array}$ & 1 & 1850 & 2020 & 3 \\
\hline ssp245-GHG & $\begin{array}{l}\text { Extension of at least one hist-GHG simulation through the } 21 \text { st century } \\
\text { using the SSP2- } 4.5 \text { greenhouse gas concentrations (WMGHGs) }\end{array}$ & 2 & 2021 & 2100 & 1 \\
\hline hist-stratO3 & Stratospheric-ozone-only historical simulations (stratospheric ozone) & 2 & 1850 & 2020 & 3 \\
\hline ssp245-stratO3 & $\begin{array}{l}\text { Extension of at least one hist-stratO3 simulation through the } 21 \text { st century } \\
\text { using SSP2-4.5 stratospheric ozone concentrations (stratospheric ozone) }\end{array}$ & 2 & 2021 & 2100 & 1 \\
\hline hist-sol & Solar-only historical simulations (solar irradiance) & 3 & 1850 & 2020 & 3 \\
\hline hist-volc & Volcanic-only historical simulations (stratospheric aerosol) & 3 & 1850 & 2020 & 3 \\
\hline hist-CO2 & $\mathrm{CO}_{2}$-only historical simulations $\left(\mathrm{CO}_{2}\right)$ & 3 & 1850 & 2020 & 3 \\
\hline ssp245-aer & $\begin{array}{l}\text { Extension of at least one hist-aer simulation through the } 21 \text { st century using } \\
\mathrm{SSP} 2-4.5 \text { tropospheric aerosol concentrations/emissions }\left(\mathrm{BC}, \mathrm{OC}, \mathrm{SO}_{2}, \mathrm{SO}_{4} \text {, }\right. \\
\left.\mathrm{NO}_{x}, \mathrm{NH}_{3}, \mathrm{CO}, \mathrm{NMVOC}\right)\end{array}$ & 3 & 2021 & 2100 & 1 \\
\hline ssp245-nat & $\begin{array}{l}\text { Extension of at least one hist-nat simulation through the } 21 \text { st century using } \\
\text { SSP2-4.5 solar and volcanic forcing (solar irradiance, stratospheric aerosol) }\end{array}$ & 3 & 2021 & 2100 & 1 \\
\hline hist-all-aer2 & $\begin{array}{l}\text { historical with alternate estimates of anthropogenic aerosol emissions/ } \\
\text { concentrations (as historical: WMGHGs, } \mathrm{BC}, \mathrm{OC}, \mathrm{SO}_{2}, \mathrm{SO}_{4}, \mathrm{NO}_{x}, \mathrm{NH}_{3} \text {, } \\
\mathrm{CO}, \mathrm{NMVOC} \text {, nitrogen deposition, ozone, stratospheric aerosols, solar irradi- } \\
\text { ance, land use) }\end{array}$ & 3 & 1850 & 2020 & 3 \\
\hline hist-all-nat2 & $\begin{array}{l}\text { historical with alternate estimates of solar and volcanic forcing (as historical: } \\
\text { WMGHGs, } \mathrm{BC}, \mathrm{OC}, \mathrm{SO}_{2}, \mathrm{SO}_{4}, \mathrm{NO}_{x}, \mathrm{NH}_{3}, \mathrm{CO}, \mathrm{NMVOC} \text {, nitrogen deposi- } \\
\text { tion, ozone, stratospheric aerosols, solar irradiance, land use) }\end{array}$ & 3 & 1850 & 2020 & 3 \\
\hline
\end{tabular}

* 2015-2100 segments of the simulations are driven by the SSP2-4.5 emission scenario.

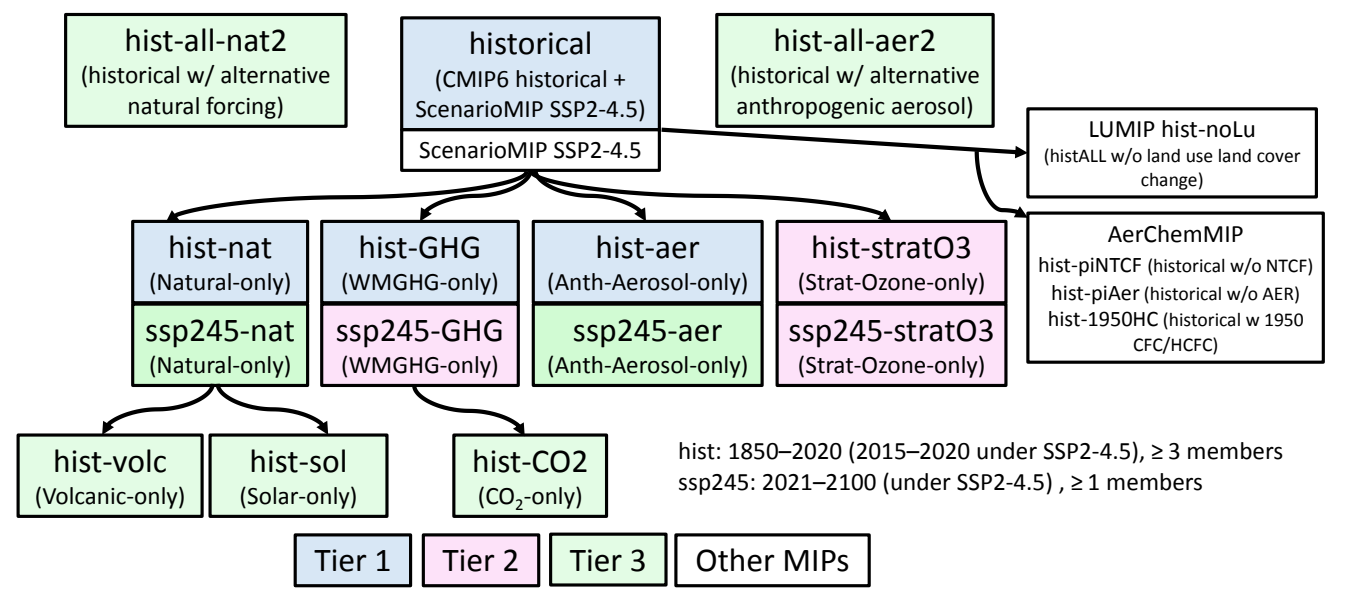

Figure 1. Schematic of the relationships of the various experiments proposed under DAMIP and other model intercomparison projects. Solid arrows indicate the decomposition into separated forced responses. 
al., 2013, 2014; Marvel et al., 2015b; Knutti and Rugenstein, 2015). We thus recommend that the validity of the additivity assumption is considered in studies using DAMIP simulations. The appropriateness of the "only" or "all-but" approach depends on the scientific question being asked, for instance whether the intention is to understand how the climate system responds to a given factor (in which case the "only" approach would be best), or to detect the contribution of a particular forcing to observed climate change (in which the "all-but" approach may be best). DAMIP will follow a combination of the "only" and "all-but" approaches. For instance, the response to anthropogenic forcing can be diagnosed from planned DAMIP experiments by taking the difference of the historical and historical natural-only experiments, an "allbut" design, whereas the response to greenhouse gases can be determined directly from the historical greenhouse-gasonly experiment, an "only" design. A major consideration is that the proposed design allows direct comparison against the attribution-relevant simulations of CMIP5. The final design reflects a compromise, allowing DAMIP simulations to be used to address a number of scientific questions whilst limiting the computational demand of the experiments.

\subsection{Tier 1 experiments}

DAMIP simulations build on the preindustrial control (piControl) simulation, which forms part of the DECK, and the CMIP6 historical simulation (Eyring et al., 2016) on which all DAMIP historical simulations are based. All simulations used in DAMIP are driven by $\mathrm{CO}_{2}$ concentration rather than $\mathrm{CO}_{2}$ emissions. In common with all other CMIP6 simulations, concentrations of the other well-mixed greenhouse gases (WMGHGs) are also specified in DAMIP simulations. We request at least three ensemble members with different initial conditions for each historical individual forcing experiment and recommend that modelling groups which cannot afford to do this for all requested runs start by carrying out at least three-member ensembles of the Tier 1 simulations. We recommend that ensemble members are initiated by choosing well-separated initial states from a control simulation.

In order to maximize the signal-to-noise ratio, and to facilitate the comparison with the most recent climate observations, it is often desirable to include data from the most recent years in D\&A analyses. Given that the CMIP6 historical simulation finishes in 2014, we therefore request that modelling groups extend all DAMIP historical simulations to 2020 using the SSP2-4.5 forcings. A similar approach was applied in CMIP5 with D\&A simulations extended from 2006 to 2012 using RCP 4.5 forcings. While this approach has the disadvantage that forcings in the final years of the simulations are estimated rather than directly observed, and in the case of CMIP5 there was discussion about whether differences in forcing over the post-2005 period could have contributed to differences in simulated and observed temperature trends over the early 21st century (Santer et al., 2013;
Huber and Knutti, 2014; Schmidt et al., 2014), in practice, barring a major volcanic eruption such forcings are unlikely to diverge strongly from reality (see Box 9.2 of Flato et al., 2013). Moreover, as long as the use of projected forcings in the post-2014 period is made clear, as it is here, investigators can make their own informed decision of whether or not to include the post-2014 period in their analyses. SSP2-4.5 was chosen because of its intermediate level of greenhouse gas emissions and its future aerosol and land use changes which are representative of a broad range of Shared Socioeconomic Pathway (SSP)-based integrated assessment model projections. A finish date of 2020 was chosen because it will allow contemporary observations to be included in detection and attribution studies cited in the Sixth IPCC Assessment Report, without extending too far into the future. Four experiments are requested under Tier 1, each of which should cover the 1850-2020 period and comprise at least three simulations with different initial conditions.

CMIP6 historical (1850-2014) \& SSP2-4.5 of ScenarioMIP (2015-2020) (historical): This includes the CMIP6 historical simulations (Eyring et al., 2016), the extension of those simulations to 2020 under the SSP2-4.5 scenario, and the generation of at least two additional (thus three total) members with different initial conditions. For brevity, we call this CMIP6 historical + SSP2-4.5 experiment "historical" in this paper. Modelling groups should provide the output data under the labels of the CMIP6 historical runs (1850-2014) and the SSP2-4.5 runs of ScenarioMIP (O'Neill et al., 2016) (2015-2020). Time-evolving solar forcing, and stratospheric aerosol ramping up towards the piControl background level should be prescribed over the 2015-2020 period as specified by ScenarioMIP (O'Neill et al., 2016).

hist-nat: These historical natural-only simulations resemble the historical simulations but are forced with only solar and volcanic forcings from the historical simulations, similarly to the CMIP5 historicalNat experiment. Together with the historical and piControl simulations, such simulations will allow the attribution of observed changes to anthropogenic and natural influences.

hist-GHG: These historical greenhouse-gas-only simulations resemble the historical simulations but instead are forced by well-mixed greenhouse gas changes only, similarly to the CMIP5 historicalGHG experiment. historical, hist-nat, and hist-GHG will allow the attribution of observed climate change to natural, greenhouse gas, and other anthropogenic components. Models with interactive chemistry schemes should either turn off the chemistry or use a preindustrial climatology of stratospheric and tropospheric ozone in their radiation schemes. This will ensure that tropospheric and stratospheric ozone are held fixed in all these simulations, and simulated responses in models with and without coupled chemistry are comparable. By comparison, in CMIP5 some models included changes in ozone in their greenhouse-gasonly simulations while others did not (Gillett et al., 2013a; 
Jones et al., 2013; Bindoff et al., 2013), making it harder to compare responses between models.

hist-aer: These historical aerosol-only simulations resemble the historical simulations but are forced by changes in aerosol forcing only. As discussed in the introduction, such simulations should allow the response to aerosols to be better constrained and physically understood, and they may also allow the response to greenhouse gases to be better constrained (Ribes et al., 2015). Two experimental designs are proposed for anthropogenic aerosol-only runs depending on whether the model concerned includes a complete representation of atmospheric chemistry. For models in which greenhouse gas concentrations do not influence aerosol concentrations, and aerosol precursor concentrations do not influence ozone concentrations, we request historical simulations forced by anthropogenic aerosol concentrations only or aerosol and aerosol precursor emissions only as in the historical simulation (sulfur dioxide; sulfate; black carbon, $\mathrm{BC}$; organic carbon, OC; ammonia; carbon monoxide; $\mathrm{NO}_{x}$ and nonmethane volatile organic compounds, NMVOCs). For models with interactive atmospheric chemistry in which aerosol and greenhouse-gas concentrations interact, we recommend an alternative experimental design. Changes in well-mixed GHGs, aerosol precursors, and ozone precursors should be prescribed as in the historical simulations. However, in the radiation scheme, the concentrations of well-mixed GHGs and the ozone climatology from the piControl runs should be used. This procedure will allow the simulation of aerosol burdens and the associated climate influence consistent with the historical simulations, hence allowing output from historical simulations and aerosol-only simulations to be meaningfully compared.

\subsection{Tier 2 experiments}

DAMIP Tier 2 experiments include experiments to enable observationally constrained projections (Stott and Kettleborough, 2002; Stott and Jones, 2012; Gillett, et al., 2012; Shiogama et al., 2016) and experiments to facilitate the attribution of observed changes to stratospheric ozone changes (Gillett et al., 2013b; Lott et al., 2013). Before performing the future simulations of DAMIP, modelling groups are asked to complete at least one SSP2-4.5 simulation of ScenarioMIP up to 2100. Minimum ensemble sizes are three for the historical simulations and one for the future simulations, though modelling groups are encouraged to run larger ensembles if resources allow.

ssp245-GHG: This comprises an extension of at least one hist-GHG simulation to 2100 using the SSP2-4.5 wellmixed greenhouse gas concentrations. ssp245-GHG, ssp245nat (see Sect. 2.3), and SSP2-4.5 will allow the simulated future responses to greenhouse gases, natural-forcing, and other forcing to be separated and constrained separately based on regression coefficients derived from observations, hence allowing observationally constrained projections to be derived. As in hist-GHG, models with interactive chemistry schemes should either run with the chemistry scheme turned off or use a preindustrial climatology of ozone in the radiation scheme.

hist-stratO3: These simulations resemble the historical simulations but are forced by changes in stratospheric ozone concentrations only. They will allow an improved characterization of the response to stratospheric ozone changes, which have played an important role in driving circulation changes in the Southern Hemisphere and temperature changes in the stratosphere, as well as the facilitaton of attribution studies of the response to stratospheric ozone change (e.g., Gillett et al., 2013b). Such experiments were not included as standard in CMIP5, although a small number of modelling groups carried them out. In models with coupled chemistry, the chemistry scheme should be turned off, and the simulated ensemble mean monthly mean 3-D stratospheric ozone concentrations from the historical simulations should be prescribed, since previous studies have indicated that the 3-D structure of ozone trends is an important driver of the tropospheric response (e.g., Waugh et al., 2009, Crook et al., 2008). Tropospheric ozone should be fixed at 3-D long-term monthly mean piControl values, with grid cells having an ozone concentration below $100 \mathrm{ppbv}$ in the piControl climatology for a given month classed as tropospheric. In models without coupled chemistry the same stratospheric ozone prescribed in the historical simulation should be prescribed. Note that DAMIP does not include simulations isolating the effects of tropospheric ozone changes.

ssp245-stratO3: These simulations are extensions of the hist-stratO3 simulations to 2100 following the ozone concentrations specified for the SSP2-4.5 scenario. Stratospheric ozone is projected to recover following the successful implementation of the Montreal Protocol and its amendments (WMO, 2014). These simulations will facilitate a robust multi-model assessment of the climate effects of this recovery on Southern Hemisphere climate and stratospheric temperature.

\subsection{Tier 3 experiments}

DAMIP Tier 3 experiments consist of solar, volcanic, and $\mathrm{CO}_{2}$ individual forcing experiments, an extension of the aerosol-only and natural-only simulation to 2100 and perturbed forcing experiments. Minimum ensemble sizes are three for the historical simulations and one for the future simulations.

hist-sol: These simulations resemble the hist-nat simulations except that hist-sol simulations are driven by solar forcing only. The potential importance of solar forcing in particular for regional climate variability is becoming increasingly evident (Gray et al., 2010; Seppälä et al., 2014). Because of its prominent approximately 11 -year cycle, solar variability could offer a degree of predictability for regional climate variability. Foreseeable fluctuations in solar output 
could help reduce the uncertainty of future regional climate predictions on decadal timescales. However there are still large uncertainties in the atmospheric solar signal and its transfer mechanisms including changes in total and spectral solar irradiance as well as in solar-driven energetic particles, and there is uncertainty in the significance and amplitude of the climate response to solar changes due to the presence of internal variability. Recent work suggests a lagged response in the North Atlantic European region due to atmosphereocean coupling (Gray et al., 2013, Scaife et al., 2013) as well as a synchronization of decadal NAO variability through the solar cycle (Thiéblemont et al., 2015). Recent modelling efforts have made progress in defining the prerequisites to simulate solar influence on regional climate more realistically but the lessons learned from CMIP5 show that a more systematic analysis of climate models within CMIP6 is required to better understand the differences in model responses to solar forcing (Mitchell et al., 2015; Misios et al., 2016; Hood et al., 2015). In particular the role of solar-induced ozone changes and the need to prescribe spectrally resolved solar irradiance variations - and therefore the need for a suitable resolution in the model's shortwave radiation scheme - are becoming increasingly evident. The proposed hist-sol experiment will facilitate the characterization of each model's solar signal and allow for a more systematic analysis of the differences in model responses. The hist-sol simulations will also allow the estimation of the effect of solar forcing on observations separately from that of volcanism (rather than in combination with volcanism using hist-nat), which is essential for the quantification of the solar signal over the historical period.

hist-volc: The hist-volc simulations resemble the hist-nat simulations except that the hist-volc simulations are driven by stratospheric aerosol forcing only. The hist-volc experiments will facilitate detection and attribution studies on volcanic influence. Careful evaluation of a model's volcanic response may inform its use for geoengineering simulations, such as those in GeoMIP (Kravitz et al., 2013, 2015). In addition, it will be possible to test additivity of the responses to these natural forcings (Gillett et al., 2004; Shiogama et al., 2013) by comparing the sum of the hist-volc and hist-sol responses with the hist-nat response.

hist-CO2: These are historical simulations driven by observed changes in $\mathrm{CO}_{2}$ concentration only as in historical. One approach to observationally constraining the ratio of warming to cumulative $\mathrm{CO}_{2}$ emissions, a policy-relevant climate metric known as the TCRE, requires an estimate of historical $\mathrm{CO}_{2}$-attributable warming, but detection and attribution analyses typically only provide an estimate of warming attributable to changes in all well-mixed greenhouse gases (Gillett et al., 2013a). Together with hist-GHG simulations these simulations would allow the ratio of $\mathrm{CO}_{2}$-attributable to GHG-attributable warming to be estimated and, hence, more robust estimates of TCRE to be obtained. Further, observationally constrained estimates of the TCR typically as- sume a perfect correlation between TCR and warming in hist-GHG across models, but in fact there is considerable spread in this ratio (Gillett et al., 2013a). These simulations will allow the reasons for this spread to be investigated and, hence, for the better characterization of uncertainties in TCR.

ssp245-aer: This involves an extension of at least one of the hist-aer simulations to 2100 using SSP2-4.5 aerosol concentrations/emissions. Together with SSP2-4.5 and ssp245nat, this will allow observationally constrained projections of future climate to be derived based on separating past and future climate change into components associated with natural forcings, aerosols, and other anthropogenic forcings (wellmixed greenhouse gases, ozone, and land use change). Such an approach may give more accurate estimates of uncertainties than the more usual approach in which climate change is separated into natural, well-mixed greenhouse gas, and other anthropogenic (aerosols, ozone, and land use change) components (e.g., Ribes et al., 2015). These simulations will also allow the more robust characterization of the response to future aerosol changes, without conflating these changes with the responses to ozone and land use changes.

ssp245-nat: This involves an extension of at least one of the hist-nat simulations to 2100 following SSP2-4.5 solar and volcanic forcing. The future solar forcing data recommended for CMIP6 has a downward trend (Matthes et al., 2016), and stratospheric aerosol is prescribed to ramp up from its level in 2014 to the background level specified in piControl over the 2015-2025 period (O'Neill et al., 2016). ssp245-nat may be used to investigate effects of these forcing changes on future climate change projections. Together with SSP2-4.5 and ssp245-GHG, ssp245-nat will allow observationally constrained projections of future climate to be derived based on separating past and future climate change into components associated with natural forcing, well-mixed greenhouse gases, and other anthropogenic forcing factors.

hist-all-aer2 and hist-all-nat2: The final two sets of simulations, hist-all-aer2 and hist-all-nat2, are identical to the historical simulation (including the extension to 2020 with SSP2-4.5), except that they contain alternative estimates of the aerosol forcing and natural forcings, respectively. Standard attribution analyses sample over internal variability, and in some cases sample over model uncertainty and observational uncertainty (e.g., Bindoff et al., 2013). However, if these analyses use a multi-model ensemble in which all models use the same set of forcings, then the contribution of forcing uncertainty to the full uncertainty in the results is neglected. Hence we propose simulations with different estimates of historical forcings to explore this source of uncertainty. We focus here on the uncertainties in aerosol emissions/concentrations and natural forcings since these sources of forcing uncertainty are expected to be the most important for global climate. Investigators could for example carry out attribution analyses using the hist-all-aer2, hist-GHG, and hist-nat simulations to address the contribution of aerosol forcing uncertainty to global attribution results, and simi- 
Table 2. Synergies with DECK, CMIP6 historical, and other MIPs.

\begin{tabular}{llll}
\hline $\begin{array}{l}\text { MIP or } \\
\text { project }\end{array}$ & Simulations in MIP & $\begin{array}{l}\text { Simulations in } \\
\text { DAMIP }\end{array}$ & Area of synergy \\
\hline DECK $^{\mathrm{a}}$ & piControl, 1pctCO2 & All & $\begin{array}{l}\text { piControl is essential for estimating internal variability. Thus we } \\
\text { recommend that modelling groups perform a 500-year or longer } \\
\text { piControl run to allow robust estimates of internal variability. } \\
\text { 1pctCO2 is needed for observationally constrained estimates of } \\
\text { TCR and TCRE. }\end{array}$ \\
& & & \\
\hline
\end{tabular}

\begin{tabular}{llll}
\hline $\begin{array}{l}\text { CMIP6 } \\
\text { historical } \\
\text { simulations }\end{array}$ & All & $\begin{array}{l}\text { historical, hist-nat, } \\
\text { hist-GHG, hist-aer, } \\
\text { hist-stratO3, hist-volc, } \\
\text { hist-sol, hist-CO2 }\end{array}$ & $\begin{array}{l}\text { All the historical experiments of DAMIP are based on the } \\
\text { CMIP6 historical simulations and allow refined understanding } \\
\text { of the contribution of individual forcing components to climate } \\
\text { variations and change in the CMIP6 historical simulations. }\end{array}$ \\
\hline ScenarioMIP $^{\mathrm{b}}$ & SSP2-4.5 & $\begin{array}{l}\text { historical, hist-nat, } \\
\text { hist-GHG, hist-aer, } \\
\text { ssp245-GHG, } \\
\text { ssp245-aer, ssp245-nat }\end{array}$ & $\begin{array}{l}\text { All DAMIP scenario simulations are based on SSP2-4.5, and } \\
\text { together with SSP2-4.5 they allow observationally constrained } \\
\text { future projections to be derived. }\end{array}$ \\
\hline AerChemMIP & $\begin{array}{l}\text { historical, hist-nat } \\
\text { hist-piNTCF } \\
\text { hist-1950HC }\end{array}$ & $\begin{array}{l}\text { hist-piNTCF (AerChemMIP) is the same as historical (DAMIP) } \\
\text { but with 1850 aerosol and ozone precursors. In hist-piAer, only } \\
\text { the aerosol precursors are kept at 1850, while the ozone precur- } \\
\text { sors follow the historical. hist-1950HC is the same as historical } \\
\text { but with 1950 CFC and HCFC concentrations. These AerChem- } \\
\text { MIP simulations may be used with DAMIP simulations to at- } \\
\text { tribute observed changes to changes in emissions of aerosol pre- } \\
\text { cursors, ozone precursors, or CFC and HCFCs, in combination } \\
\text { with natural forcings and other anthropogenic forcings. }\end{array}$ \\
& & &
\end{tabular}

\begin{tabular}{|c|c|c|c|}
\hline $\mathrm{DCPP}^{\mathrm{d}}$ & $\begin{array}{l}\text { Historical+SSP2-4.5 } \\
\text { C1.10 (Pacemaker } \\
\text { Pacific experiment) } \\
\text { C1.11 (Pacemaker } \\
\text { Atlantic experiment) }\end{array}$ & historical & $\begin{array}{l}\text { DCPP proposes a 10-member ensemble of historical up to } 2030 \\
\text { also extended with SSP2-4.5. The combinations of DAMIP and } \\
\text { DCPP/GMMIP experiments allow the assessment of the relative } \\
\text { contributions of external forcing factors and the response to the } \\
\text { PDO and AMO to historical climate change. }\end{array}$ \\
\hline GMMIP & $\begin{array}{l}\text { amip-hist, } \\
\text { hist-resIPO, } \\
\text { hist-resAMO }\end{array}$ & $\begin{array}{l}\text { historical, hist-nat, } \\
\text { hist-GHG, hist-aer }\end{array}$ & $\begin{array}{l}\text { The combination of DAMIP and DCPP/GMMIP simulations } \\
\text { allows the assessment of the relative contributions of exter- } \\
\text { nal forcing factors and internal variability to historical climate } \\
\text { change. }\end{array}$ \\
\hline LUMIP & hist-NoLu & historical & $\begin{array}{l}\text { hist-NoLu of LUMIP and historical will allow the separation of } \\
\text { the effects of land use changes and the response to other forc- } \\
\text { ings. }\end{array}$ \\
\hline RFMIP-ERF ${ }^{g}$ & $\begin{array}{l}\text { RFMIP-ERF-HistAll, } \\
\text { RFMIP-ERF-HistNat, } \\
\text { RFMIP-ERF-HistGHG, } \\
\text { RFMIP-ERF-HistAer }\end{array}$ & $\begin{array}{l}\text { historical, hist-nat, } \\
\text { hist-GHG, hist-aer, } \\
\text { ssp245-GHG, } \\
\text { ssp245-aer, ssp245-nat }\end{array}$ & $\begin{array}{l}\text { Combining radiative forcing estimated from RFMIP-ERF and } \\
\text { transient climate responses from DAMIP, we can investigate } \\
\text { how feedbacks and adjustments vary with forcing factors. }\end{array}$ \\
\hline $\begin{array}{l}\text { RFMIP- } \\
\text { SpAerg,h }\end{array}$ & $\begin{array}{l}\text { RFMIP-SpAerO3-all, } \\
\text { RFMIP-SpAerO3-aer }\end{array}$ & $\begin{array}{l}\text { historical, hist-nat, } \\
\text { hist-aer }\end{array}$ & $\begin{array}{l}\text { Combinations of DAMIP and RFMIP-SpAer simulations will } \\
\text { allow us to separate uncertainties in climate response based on } \\
\text { specified aerosol evolution from the overall uncertainties in cli- } \\
\text { mate response to specified aerosol precursor emissions. }\end{array}$ \\
\hline $\begin{array}{l}\text { GeoMIP }^{\mathrm{i}} \& \\
\text { VolMIPj }^{\mathrm{j}}\end{array}$ & All & hist-volc & $\begin{array}{l}\text { The volcanic response of models can be validated against ob- } \\
\text { servations using hist-volc, whereas GeoMIP experiments can- } \\
\text { not. Thus hist-volc experiments will provide useful context for } \\
\text { interpreting simulated responses to stratospheric aerosol across } \\
\text { models in the GeoMIP experiment. While VolMIP includes sim- } \\
\text { ulations of individual eruptions, it does not include simulations } \\
\text { of the transient response to historical eruptions and its focus } \\
\text { is on 19th century eruptions. hist-volc facilitates validation of } \\
\text { long-term transient effects against observations. }\end{array}$ \\
\hline
\end{tabular}

The reference papers are ${ }^{\mathrm{a}}$ Eyring et al. (2016), ${ }^{\mathrm{b}}$ O’Neill et al. (2016), ${ }^{\mathrm{c}}$ Collins et al. (2016), ${ }^{\mathrm{d}}$ Boer et al. (2016), ${ }^{\mathrm{e}}$ Zhou et al. (2016), ${ }^{\mathrm{f}}$ Lawrence et al. (2016), ${ }^{\mathrm{g}}$ Pincus et al. (2016),

${ }^{\mathrm{h}}$ Stevens et al. (2016), ${ }^{\mathrm{i}}$ Kravitz et al. (2015) and ${ }^{\mathrm{j}}$ Zanchettin et al. (2016). 
larly use the hist-all-nat2, hist-GHG, and hist-aer simulations to address the contribution of natural forcing uncertainty to global attribution results. These simulations could also be used to examine the role of forcing uncertainties in simulating climate trends over particular periods, such as global warming over the early 21 st century. The exact method for sampling uncertainty in the tropospheric aerosol, volcanic, and solar forcings is being developed in cooperation with the groups developing forcing data sets for CMIP6.

\section{Synergies with other model intercomparison projects}

Synergies between the CMIP6-endorsed model intercomparison projects (MIPs) are important for maximizing the value of CMIP6 and allowing us to address the WCRP grand challenges. Table 2 shows potential synergies between DAMIP, the other MIPs, and other relevant research activities.

The Decadal Climate Prediction Project (DCPP, Boer et al., 2016) and DAMIP together propose the enlargement of the ensemble size of historical and SSP2-4.5 to investigate the importance of internal variability in the past and the near future, providing reduced total computing costs if both MIPs are pursued. DCPP and the Global Monsoons Modeling Intercomparison Project (GMMIP, Zhou et al., 2016) have proposed the pacemaker 20th century historical runs (Kosaka and Xie, 2013) to understand the influences of the Interdecadal Pacific Oscillation (IPO) and the Atlantic Multidecadal Oscillation (AMO) on historical climate changes. The combination of these pacemaker experiments and DAMIP experiments will facilitate assessments of the relative contributions of external forcing factors and internal variability to historical climate change.

Closely collaborating with DAMIP, the Effective Radiative Forcing subproject of RFMIP (RFMIP-ERF, Pincus et al., 2016) has proposed experiments to estimate effective radiative forcing for all forcings combined, well-mixed greenhouse gas forcing, natural forcing, and anthropogenic aerosol forcing. Combining radiative forcing estimated from RFMIP-ERF and TCRs from DAMIP, we can investigate transient climate sensitivities (or forcing efficacies) (Hansen et al., 2005; Yoshimori and Broccoli, 2008; Shindell, 2014) for those forcing agents, which may be used to help derive observational constraints on TCR and effective climate sensitivity (Shindell, 2014; Kummer and Dessler, 2014; Gregory et al., 2015; Marvel et al., 2015a).

LUMIP (Lawrence et al., 2016) proposes historical all forcing experiments without land use and land cover changes. Combinations of these and the DAMIP experiments allow the separation of climate responses to land use and land cover changes and the other forcing agents. Lastly, while VolMIP (Zanchettin et al., 2016) includes simulations of individual eruptions it does not include simulations of the transient response to historical eruptions, except for the Tambora period in the 19th century. hist-volc of DAMIP allows better validation of long-term transient effects against observations,

\section{New variables requested by DAMIP}

The specific questions addressed by the hist-sol experiment, in particular the attribution of differences in the model responses to solar forcing and its link to different transfer mechanisms, require additional model output related to the radiation scheme and calculated or prescribed ozone chemistry. This includes zonal mean short- and longwave heating rates, as well as ozone fields (prescribed or interactively calculated). Further, a reduced set of new chemistry variables has been proposed for models with interactive chemistry schemes, including $\mathrm{O}_{2}$ and $\mathrm{O}_{3}$ photolysis rates, as well as odd oxygen total loss and production rates. These new variables may also be of interest for investigating and understanding the response to other forcings in the DAMIP simulations.

\section{Summary}

DAMIP will coordinate the climate model simulations needed to more robustly attribute global and regional climate change to anthropogenic and natural causes, to derive observationally constrained projections of future climate change, and to improve understanding of the mechanisms by which particular forcings affect climate. The Tier 1 simulations differ from those included in CMIP5 only by the inclusion of a set of simulations with aerosol changes only, which will help constrain the climate response to aerosol forcing, and also by an experimental design that ensures that results from models with and without coupled chemistry are comparable. Tiers 2 and 3 include individual forcing simulations covering the future through to the end of the century, which are needed to observationally constrain the future response to greenhouse gases, aerosols, stratospheric ozone, and natural forcing based on observed historical changes. These tiers also include additional simulations of the response to historical variations in stratospheric ozone, $\mathrm{CO}_{2}$, volcanoes, and solar forcing individually and perturbed forcing simulations to allow the contribution of forcing uncertainty to uncertainty in attribution results to be assessed for the first time.

\section{Data availability}

The model output from the DAMIP simulations described in this paper will be distributed through the Earth System Grid Federation (ESGF) with digital object identifiers (DOIs) assigned. As in CMIP5, the model output will be freely accessible through data portals after registration. In order to document DAMIP's scientific impact and enable ongoing support of DAMIP, users are asked to acknowledge CMIP6, 
DAMIP, the participating modelling groups, and the ESGF centres (see details on the CMIP Panel website at http:// www.wcrp-climate.org/index.php/wgcm-cmip/about-cmip). The DAMIP website contains updated details on the project and its progress at http://damip.lbl.gov.

Edited by: S. Valcke

Reviewed by: A. Ribes and one anonymous referee

\section{References}

Allen, M. R., Stott, P. A., Mitchell, J. F. B., Schnur, R., and Delworth, T. L.: Quantifying the uncertainty in forecasts of anthropogenic climate change, Nature, 407, 617-620, doi:10.1038/35036559, 2000.

Allen, M. R., Frame, D. J., Huntingford, C., Jones, C. D., Lowe, J. A., Meinshausen, M., and Meinshausen, N.: Warming caused by cumulative carbon emissions towards the trillionth tonne, Nature, 458, 1163-1166, doi:10.1038/nature08019, 2009.

Barnett, T., Zwiers, F., Hegerl, G., Allen, M., Crowley, T., Gillett, N., Hasselmann, K., Jones, P., Santer, B., Schnur, R., Stott, P., Taylor, K., and Tett, S.: Detecting and attributing external influences on the climate system: A review of recent advances, J. Climate, 18, 1291-1314, 2005.

Bindoff, N. L., Stott, P. A., AchutaRao, K. M., Allen, M. R., Gillett, N. P., Gutzler, D., Hansingo, K., Hegerl, G., Hu,Y., Jain, S., Mokhov, I. I., Overland, J., Perlwitz, J., Sebbari, R., and Zhang, X.: Detection and Attribution of Climate Change: from Global to Regional, in: Climate Change 2013: The Physical Science Basis. Contribution of Working Group I to the Fifth Assessment Report of the Intergovernmental Panel on Climate Change, edited by: Stocker, T. F., Qin, D., Plattner, G.-K., Tignor, M., Allen, S. K., Boschung, J., Nauels, A., Xia, Y., Bex, V., and Midgley, P. M., Cambridge University Press, Cambridge, UK and New York, NY, USA, 2013.

Boer, G. J., Smith, D. M., Cassou, C., Doblas-Reyes, F., Danabasoglu, G., Kirtman, B., Kushnir, Y., Kimoto, M., Meehl, G. A., Msadek, R., Mueller, W. A., Taylor, K., and Zwiers, F.: The Decadal Climate Prediction Project, Geosci. Model Dev. Discuss., doi:10.5194/gmd-2016-78, in review, 2016.

Boucher, O., Randall, D., Artaxo, P., Bretherton, C., Feingold, G., Forster, P., Kerminen, V.-M., Kondo, Y., Liao, H., Lohmann, U., Rasch, P., Satheesh, S. K., Sherwood, S., Stevens, B., and Zhang, X. Y.: Clouds and Aerosols, in: Climate Change 2013: The Physical Science Basis. Contribution of Working Group I to the Fifth Assessment Report of the Intergovernmental Panel on Climate Change, edited by: Stocker, T. F., Qin, D., Plattner, G.-K., Tignor, M., Allen, S. K., Boschung, J., Nauels, A., Xia, Y., Bex, V., and Midgley, P. M., Cambridge University Press, Cambridge, UK and New York, NY, USA, 2013.

Collins, W. J., Lamarque, J.-F., Schulz, M., Boucher, O., Eyring, V., Hegglin, M. I., Maycock, A., Myhre, G., Prather, M., Shindell, D., and Smith, S. J.: AerChemMIP: Quantifying the effects of chemistry and aerosols in CMIP6, Geosci. Model Dev. Discuss., doi:10.5194/gmd-2016-139, in review, 2016.

Crook, J. A., Gillett, N. P., and Keeley, S. P. E.: Sensitivity of Southern Hemisphere climate to zonal asymmetry in ozone, Geophys. Res. Lett., 35, L07806, doi:10.1029/2007GL032698, 2008.
Eyring, V., Bony, S., Meehl, G. A., Senior, C. A., Stevens, B., Stouffer, R. J., and Taylor, K. E.: Overview of the Coupled Model Intercomparison Project Phase 6 (CMIP6) experimental design and organization, Geosci. Model Dev., 9, 1937-1958, doi:10.5194/gmd-9-1937-2016, 2016.

Flato, G., Marotzke, J., Abiodun, B., Braconnot, P., Chou, S. C., Collins, W., Cox, P., Driouech, F., Emori, S., Eyring, V., Forest, C., Gleckler, P., Guilyardi, E., Jakob, C., Kattsov, V., Reason, C., and Rummukainen, M.: Evaluation of Climate Models, in: Climate Change 2013: The Physical Science Basis. Contribution of Working Group I to the Fifth Assessment Report of the Intergovernmental Panel on Climate Change, edited by: Stocker, T. F., Qin, D., Plattner, G.-K., Tignor, M., Allen, S. K., Boschung, J., Nauels, A., Xia, Y., Bex, V., and Midgley, P. M., Cambridge University Press, Cambridge, UK and New York, NY, USA, 2013.

Gagné, M. Ė., Gillett, N. P., and Fyfe, J. C.: Impact of aerosol emission controls on future Arctic sea ice cover, Geophys. Res. Lett., 42, 8481-8488, doi:10.1002/2015g1065504, 2015.

Gillett, N. P. and Von Salzen, K.: The role of reduced aerosol precursor emissions in driving near-term warming, Environ. Res. Lett., 8, 034008, doi:10.1088/1748-9326/8/3/034008, 2013.

Gillett, N. P., Wehner, M. F., Tett, S. F. B., and Weaver, A. J.: Testing the linearity of the response to combined greenhouse gas and sulfate aerosol forcing, Geophys. Res. Lett., 31, L14201, doi:10.1029/2004g1020111, 2004.

Gillett, N. P., Arora, V. K., Flato, G. M., Scinocca, J. F., and von Salzen, K.: Improved constraints on 21 st-century warming derived using 160 years of temperature observations, Geophys. Res. Lett., 39, L01704, doi:10.1029/2011g1050226, 2012.

Gillett, N. P., Arora, V. K., Matthews, D., and Allen, M. R.: Constraining the Ratio of Global Warming to Cumulative $\mathrm{CO}_{2}$ Emissions Using CMIP5 Simulations, J. Climate, 26, 6844-6858, doi:10.1175/jcli-d-12-00476.1, 2013a.

Gillett, N. P., Fyfe, J. C., and Parker, D. E.: Attribution of observed sea level pressure trends to greenhouse gas, aerosol, and ozone changes, Geophys. Res. Lett., 40, 2302-2306, doi:10.1002/grl.50500, 2013b.

Gray, L. J., Beer, J., Geller, M., Haigh, J. D., Lockwood, M., Matthes, K., Cubasch, U., Fleitmann, D., Harrison, G., Hood, L., Luterbacher, J., Meehl, G. A., Shindell, D., van Geel, B., and White, W.: Solar Influences on Climate, Rev. Geophys., 48, RG4001, doi:10.1029/2009RG000282, 2010.

Gray, L. J., Scaife, A. A., Mitchell, D. M., Osprey, S., Ineson, S., Hardiman, S., Butchart, N., Knight, J., Sutton, R., and Kodera, $\mathrm{K}$.: A lagged response to the 11 year solar cycle in observed winter Atlantic/European weather patterns, J. Geophys. Res., 118, 13405-13420, doi:10.1002/2013JD020062, 2013.

Gregory, J. M., Andrews, T., and Good, P.: The inconstancy of the transient climate response parameter under increasing $\mathrm{CO}_{2}$, Philos. T. R. Soc. A, 373, 20140417, doi:10.1098/rsta.2014.0417, 2015.

Hansen, J., Sato, M., Ruedy, R., Nazarenko, L., Lacis, A., Schmidt, G. A., Russell, G., Aleinov, I., Bauer, M., Bauer, S., Bell, N., Cairns, B., Canuto, V., Chandler, M., Cheng, Y., Del Genio, A., Faluvegi, G., Fleming, E., Friend, A., Hall, T., Jackman, C., Kelley, M., Kiang, N., Koch, D., Lean, J., Lerner, J., Lo, K., Menon, S., Miller, R., Minnis, P., Novakov, T., Oinas, V., Perlwitz, Ja., Perlwitz, Ju., Rind, D., Romanou, A., Shindell, D., Stone, P., Sun, S., Tausnev, N., Thresher, D., Wielicki, B., Wong, T., Yao, M., 
and Zhang, S.: Efficacy of climate forcings, J. Geophys. Res.Atmos., 110, D18104, doi:10.1029/2005jd005776, 2005.

Hegerl, G. C., Zwiers, F. W., Braconnot, P., Gillett, N. P., Luo, Y., Marengo Orsini, J. A., Nicholls, N., Penner, J. E., and Stott, P. A.: Understanding and Attributing Climate Change, in: Climate Change 2007: The Physical Science Basis. Contribution of Working Group I to the Fourth Assessment Report of the Intergovernmental Panel on Climate Change, edited by: Solomon, S., Qin, D., Manning, M., Chen, Z., Marquis, M., Averyt, K. B., Tignor, M., and Miller, H. L., Cambridge University Press, Cambridge, UK and New York, NY, USA, 2007.

Hood, L. L., Misios, S., Mitchell, D. M., Gray, L. J., Tourpali, K., Matthes, K., Schmidt, H., Chiodo, G., Thiéblemont, R., Rozanov, E., Shindell, D., and Krivolutsky, A.: Solar signals in CMIP-5 simulations: the ozone response, Q. J. Roy. Meteor. Soc., 141, 2670-2689, doi:10.1002/qj.2553, 2015.

Huber, M. and Knutti, R.: Natural variability, radiative forcing and climate response in the recent hiatus reconciled, Nat. Geosci., 7, 651-656, doi:10.1038/ngeo2228, 2014.

IPCC: Climate Change 2014: Synthesis Report. Contribution of Working Groups I, II and III to the Fifth Assessment Report of the Intergovernmental Panel on Climate Change, edited by: Core Writing Team, Pachauri, R. K., and Meyer, L. A., IPCC, Geneva, Switzerland, 151 pp., 2014.

Jones, G. S., Stott, P. A., and Christidis, N.: Attribution of observed historical near-surface temperature variations to anthropogenic and natural causes using CMIP5 simulations, J. Geophys. Res.Atmos., 118, 4001-4024, doi:10.1002/jgrd.50239, 2013.

Kettleborough, J. A., Booth, B. B. B., Stott, P. A., and Allen, M. R.: Estimates of uncertainty in predictions of global mean surface temperature, J. Climate, 20, 843-855, doi:10.1175/jcli4012.1, 2007.

Knutti, R. and Hegerl, G. C.: The equilibrium sensitivity of the Earth's temperature to radiation changes, Nat. Geosci. 1, 735743, 2008.

Knutti, R. and Rugenstein, M. A. A.: Feedbacks, climate sensitivity and the limits of linear models, Philos. T. R. Soc. A, 373, 20150146, doi:10.1098/rsta.2015.0146, 2015.

Kosaka, Y. and Xie, S.-P.: Recent global-warming hiatus tied to equatorial Pacific surface cooling, Nature, 501, 403-407, 2013.

Kravitz, B., Caldeira, K., Boucher, O., Robock, A., Rasch, P. J., Alterskjær, K., Karam, D. B., Cole, J. N. S., Curry, C. L., Haywood, J. M., Irvine, P. J., Ji, D., Jones, A., Kristjánsson, J. E., Lunt, D. J., Moore, J. C., Niemeier, U., Schmidt, H., Schulz, M., Singh, B., Tilmes, S., Watanabe, S., Yang, S., and Yoon, J.-H.: Climate model response from the Geoengineering Model Intercomparison Project (GeoMIP), J. Geophys. Res.-Atmos., 118, 8320-8332, doi:10.1002/jgrd.50646, 2013.

Kravitz, B., Robock, A., Tilmes, S., Boucher, O., English, J. M., Irvine, P. J., Jones, A., Lawrence, M. G., MacCracken, M., Muri, H., Moore, J. C., Niemeier, U., Phipps, S. J., Sillmann, J., Storelvmo, T., Wang, H., and Watanabe, S.: The Geoengineering Model Intercomparison Project Phase 6 (GeoMIP6): simulation design and preliminary results, Geosci. Model Dev., 8, 33793392, doi:10.5194/gmd-8-3379-2015, 2015.

Kummer, J. R. and Dessler, A. E.: The impact of forcing efficacy on the equilibrium climate sensitivity, Geophys. Res. Lett., 41, 3565-3568, doi:10.1002/2014gl060046, 2014.
Lawrence, D. M., Hurtt, G. C., Arneth, A., Brovkin, V., Calvin, K. V., Jones, A. D., Jones, C. D., Lawrence, P. J., de NobletDucoudré, N., Pongratz, J., Seneviratne, S. I., and Shevliakova, E.: The Land Use Model Intercomparison Project (LUMIP) contribution to CMIP6: rationale and experimental design, Geosci. Model Dev., 9, 2973-2998, doi:10.5194/gmd-9-29732016, 2016.

Lott, F. C., Stott, P. A., Mitchell, D. M., Christidis, N., Gillett, N. P., Haimberger, L., Perlwitz, J., and Thorne, P. W.: Models versus radiosondes in the free atmosphere: A new detection and attribution analysis of temperature, J. Geophys. Res.-Atmos., 118, 2609-2619, doi:10.1002/jgrd.50255, 2013.

Marvel, K., Schmidt, G. A., Miller, R. L., and Nazarenko, L. S.: Implications for climate sensitivity from the response to individual forcings, Nature Clim. Change, 6, 386-389, doi:10.1038/nclimate2888, 2015a.

Marvel, K., Schmidt, G. A., Shindell, D., Bonfils, C., LeGrande, A. N., Nazarenko, L., and Tsigaridis, K.: Do responses to different anthropogenic forcings add linearly in climate models?, Environ. Res. Lett., 10, 104010, doi:10.1088/1748-9326/10/10/104010, 2015b.

Matthes, K., Funke, B., Anderson, M. E., Barnard, L., Beer, J., Charbonneau, P., Clilverd, M. A., Dudok de Wit, T., Haberreiter, M., Hendry, A., Jackman, C. H., Kretschmar, M., Kruschke, T., Kunze, M., Langematz, U., Marsh, D. R., Maycock, A., Misios, S., Rodger, C. J., Scaife, A. A., Seppälä, A., Shangguan, M., Sinnhuber, M., Tourpali, K., Usoskin, I., van de Kamp, M., Verronen, P. T., and Versick, S.: Solar Forcing for CMIP6 (v3.1), Geosci. Model Dev. Discuss., doi:10.5194/gmd-2016-91, in review, 2016.

Meehl, G. A., Washington, W. M., Ammann, C. M., Arblaster, J. M., Wigley, T. M. L., and Tebaldi, C. Combinations of natural and anthropogenic forcings in Twentieth-Century climate, J. Climate, 17, 3721-3727, 2004.

Meehl, G. A., Covey, C., Delworth, T., Latif, M., McAvaney, B., Mitchell, J. F. B., Stouffer, R. J., and Taylor, K. E.: The WCRP CMIP3 multimodel dataset: A new era in climate change research, B. Am. Meteorol. Soc., 88, 1383-1394, doi:10.1175/BAMS-88-9-1383, 2007.

Meehl, G. A., Arblaster, J. M., Fasullo, J. T., Hu, A., and Trenberth, K. E.: Model-based evidence of deep-ocean heat uptake during surface-temperature hiatus periods, Nature Clim. Change, 1, 360-364, doi:10.1038/nclimate1229, 2011.

Misios, S., Mitchell, D. M., Gray, L. J., Tourpali, K., Matthes, K., Hood, L., Schmidt, H., Chiodo, G., Thiéblemont, R., Rozanov, E., and Krivolutsky, A.: Solar signals in CMIP-5 simulations: effects of atmosphere-ocean coupling, Q. J. Roy. Meteor. Soc., 142, 928-941, doi:10.1002/qj.2695, 2016.

Mitchell, D., Misios, S., Gray, L. J., Tourpali, K., Matthes, K., Hood, L., Schmidt, H., Chiodo, G., Thiéblemont, R., Rozanov, E., Shindell, D., and Krivolutsky, A.: Solar signals in CMIP-5 simulations: the stratospheric pathway, Q. J. Roy. Meteor. Soc., 141, 2390-2403, doi:10.1002/qj.2530, 2015.

Myhre, G., Boucher, O., Breon, F.-M., Forster, P., and Shindell, D.: Declining uncertainty in transient climate response as $\mathrm{CO}_{2}$ forcing dominates future climate change, Nat. Geosci., 8, 181-185, doi:10.1038/ngeo2371, 2015.

O’Neill, B. C., Tebaldi, C., van Vuuren, D. P., Eyring, V., Friedlingstein, P., Hurtt, G., Knutti, R., Kriegler, E., Lamarque, J.-F., 
Lowe, J., Meehl, G. A., Moss, R., Riahi, K., and Sanderson, B. M.: The Scenario Model Intercomparison Project (ScenarioMIP) for CMIP6, Geosci. Model Dev., 9, 3461-3482, doi:10.5194/gmd-9-3461-2016, 2016.

Pincus, R., Forster, P. M., and Stevens, B.: The Radiative Forcing Model Intercomparison Project (RFMIP): experimental protocol for CMIP6, Geosci. Model Dev., 9, 3447-3460, doi:10.5194/gmd-9-3447-2016, 2016.

Ribes, A. and Terray, L.: Application of regularised optimal fingerprinting to attribution. Part II: application to global near-surface temperature, Clim. Dynam., 41, 2837-2853, doi:10.1007/s00382-013-1736-6, 2013.

Ribes, A., Gillett, N. P., and Zwiers, F. W.: Designing detection and attribution simulations for CMIP6 to optimize the estimation of greenhouse gas-induced warming, J. Climate, 28, 3435-3438, doi:10.1175/jcli-d-14-00691.1, 2015.

Rogelj, J., Meinshausen, M., and Knutti, R.: Global warming under old and new scenarios using IPCC climate sensitivity range estimates, Nature Clim. Change, 2, 248-253, 2012.

Rotstayn, L. D., Collier, M. A., Chrastansky, A., Jeffrey, S. J., and Luo, J.-J.: Projected effects of declining aerosols in RCP4.5: unmasking global warming?, Atmos. Chem. Phys., 13, 1088310905, doi:10.5194/acp-13-10883-2013, 2013.

Santer, B. D., Painter, J. F., Bonfils, C., Mears, C. A., Solomon, S., Wigley, T. M. L., Gleckler, P. J., Schmidt, G. A., Doutriaux, C., Gillett, N. P., Taylor, K. E., Thorne, P. W., and Wentz, F. J.: Human and natural influences on the changing thermal structure of the atmosphere, P. Natl. Acad. Sci. USA, 110, 17235-17240, doi:10.1073/pnas.1305332110, 2013.

Scaife, A. A., Ineson, S., Knight, J., R., Gray, L. J., Kodera, K., and Smith, D. M.: A mechanism for lagged North Atlantic climate response to solar variability, Geophys. Res. Lett., 40, 434-439, doi:10.1002/grl.50099, 2013.

Schaller, N., Cermak, J., Wild, M., and Knutti, R.: The sensitivity of the modeled energy budget and hydrological cycle to $\mathrm{CO}_{2}$ and solar forcing, Earth Syst. Dynam., 4, 253-266, doi:10.5194/esd4-253-2013, 2013.

Schaller, N., Sedlacek, J., and Knutti, R.: The asymmetry of the climate system's response to solar forcing changes and its implications for geoengineering scenarios, J. Geophys. Res., 119, 5171-5184, doi:10.1002/2013JD021258, 2014.

Schmidt, G. A., Shindell, D. T., and Tsigaridis, K.: Reconciling warming trends, Nat. Geosci., 7, 158-160, doi:10.1038/ngeo2105, 2014.

Seppälä, A., Matthes, K., Randall, C., and Mironova, I.: What is the solar influence on climate? - Overview of activities during CAWSES-II, Progress in Earth and Planetary Science, 1, 24, doi:10.1186/s40645-014-0024-3, 2014.

Shindell, D. T.: Inhomogeneous forcing and transient climate sensitivity, Nature Clim. Change, 4, 274-277, doi:10.1038/nclimate2136, 2014.

Shiogama, H., Emori, S., Takahashi, K., Nagashima, T., Ogura, T., Nozawa, T., and Takemura, T.: Emission scenario dependency of precipitation on global warming in the MIROC3.2 model, J. Climate, 23, 2404-2417, 2010a.

Shiogama, H., Hanasaki, N., Masutomi, Y., Nagashima, T., Ogura, T., Takahashi, K., Hijioka, Y., Takemura, T., Nozawa, T., and Emori, S.: Emission scenario dependencies in climate change as- sessments of the hydrological cycle, Climatic Change, 99, 321329, doi:10.1007/s10584-009-9765-1, 2010b.

Shiogama, H., Stone, D. A., Nagashima, T., Nozawa, T., and Emori, S.: On the linear additivity of climate forcing-response relationships at global and continental scales, Int. J. Climatol., 33, 2542 2550, 2013.

Shiogama, H., Stone, D., Emori, S., Takahashi, K., Mori, S., Maeda, A., Ishizaki, Y., and Allen, M. R.: Predicting future uncertainty constraints on global warming projections, Sci. Rep., 6, 18903, doi:10.1038/srep18903, 2016.

Stevens, B., Fiedler, S., Kinne, S., Peters, K., Rast, S., Müsse, J., Smith, S. J., and Mauritsen, T.: Simple Plumes: A parameterization of anthropogenic aerosol optical properties and an associated Twomey effect for climate studies, Geosci. Model Dev. Discuss., doi:10.5194/gmd-2016-189, in review, 2016.

Stone, D. A. and Pall., P.: A benchmark estimate of the effect of anthropogenic emissions on the ocean surface, in preparation, 2016.

Stott, P., Good, P., Jones, G., Gillett, N., and Hawkins, E.: The upper end of climate model temperature projections is inconsistent with past warming, Environ. Res. Lett., 8, 014024, doi:10.1088/17489326/8/1/014024, 2013.

Stott, P. A. and Jones, G. S.: Observed 21st century temperatures further constrain likely rates of future warming, Atmos. Sci. Lett., 13, 151-156, doi:10.1002/asl.383, 2012.

Stott, P. A. and Kettleborough, J. A.: Origins and estimates of uncertainty in predictions of twenty-first century temperature rise, Nature, 416, 723-726, doi:10.1038/416723a, 2002.

Stott, P. A., Mitchell, J. F. B., Allen, M. R., Delworth, T. L., Gregory, J. M., Meehl, G. A., and Santer, B. D.: Observational constraints on past attributable warming and predictions of future global warming, J. Climate, 19, 3055-3069, doi:10.1175/jcli3802.1, 2006.

Stouffer, R. J., Eyring, V., Meehl, G. A., Bony, S., Senior, C., Stevens, B., and Taylor, K. E., CMIP5 scientific gaps and recommendations for CMIP6, B. Am. Meteorol. Soc., doi:10.1175/BAMS-D-15-00013.1, in press, 2016.

Taylor, K. E., Stouffer, R. J., and Meehl, G. A.: An overview of CMIP5 and the experiment design, B. Am. Meteorol. Soc., 93, 485-498, doi:10.1175/BAMS-D-11-00094.1, 2012.

Thiéblemont, R., Matthes, K., Omrani, N.-E., Kodera, K., and Hansen, F.: Solar forcing synchronizes decadal North Atlantic climate variability, Nat. Comm., 6, 8268, doi:10.1038/ncomms9268, 2015.

Watanabe, M., Shiogama, H., Tatebe, H., Hayashi, M., Ishii, M., and Kimoto, M.: Contribution of natural decadal variability to global warming acceleration and hiatus, Nature Clim. Change, 4 , 893-897, doi:10.1038/nclimate2355, 2014.

Waugh, D. W., Oman, L., Newman, P. A., Stolarski, R. S., Pawson, S., Nielsen, J. E., and Perlwitz, J.: Effect of zonal asymmetries in stratospheric ozone on simulated Southern Hemisphere climate trends, Geophys. Res. Lett., 36, L18701, doi:10.1029/2009GL040419, 2009.

WMO: Scientific Assessment of Ozone Depletion: 2014, World Meteorological Organization, Global Ozone Research and Monitoring Project - Report No. 55, 416 pp., Geneva, Switzerland, 2014.

Yoshimori, M. and Broccoli, A. J.: Equilibrium response of an atmosphere-mixed layer ocean model to different radiative forc- 
ing agents: Global and zonal mean response, J. Climate, 21, 4399-4423, doi:10.1175/2008jcli2172.1, 2008.

Zanchettin, D., Khodri, M., Timmreck, C., Toohey, M., Schmidt, A., Gerber, E. P., Hegerl, G., Robock, A., Pausata, F. S. R., Ball, W. T., Bauer, S. E., Bekki, S., Dhomse, S. S., LeGrande, A. N., Mann, G. W., Marshall, L., Mills, M., Marchand, M., Niemeier, U., Poulain, V., Rozanov, E., Rubino, A., Stenke, A., Tsigaridis, K., and Tummon, F.: The Model Intercomparison Project on the climatic response to Volcanic forcing (VolMIP): experimental design and forcing input data for CMIP6, Geosci. Model Dev., 9, 2701-2719, doi:10.5194/gmd-9-2701-2016, 2016.
Zhang, X., Zwiers, F. W., Hegerl, G. C., Lambert, F. H., Gillett, N. P., Solomon, S., Stott, P. A., and Nozawa, T.: Detection of human influence on twentieth-century precipitation trends, Nature, 448, 461-465, doi:10.1038/nature06025, 2007.

Zhou, T., Turner, A. G., Kinter, J. L., Wang, B., Qian, Y., Chen, X., Wu, B., Wang, B., Liu, B., Zou, L., and He, B.: GMMIP (v1.0) contribution to CMIP6: Global Monsoons Model Inter-comparison Project, Geosci. Model Dev., 9, 3589-3604, doi:10.5194/gmd-9-3589-2016, 2016. 